\title{
Graphic Novels as Self-Conscious Contemplative Metatexts: Redefining Comics and Participating in Theoretical Discourse
}

\author{
Moula Evangelia \\ Secondary Education, Rhodes, Greece
}

\author{
Christodoulidou Louiza \\ University of the Aegean, Rhodes, Greece
}

\begin{abstract}
The long-term biased critical reception of comics did not allow the medium's theoretical remodeling, the highlighting of its multidimensionality and complexity, and its establishment as a self-sufficient and serious narrative medium. The creators of graphic novels in an attempt to upgrade and restore their "ancestors"” cultural status and to eliminate the negative stigma of the medium, by taking advantage of the self-referencing techniques, they try to redefine comics and reframe the field of their social practice. Graphic novels, even more, either allusively or straightforwardly, aquire metatextual quality, by exercising critique on the artistic phenomenon in general and on comics' history and theory in particular. Self-referentiality and metatextuality function as 'internal legitimization apparatuses of the medium and provide graphic novels the right to participate in the theoretical discourse, negotiate or even rearticulate it.
\end{abstract}

Keywords: graphic novels, comics, self-referentiality, metatextuality

\section{Introduction}

Comics had since their origination been underappreciated and were not considered to be cultural products aesthetically or pedagogically appropriate, until the advent of graphic novels. Being able to fly underneath the radar of the strict criteria of adult censorship, they incited parents' anxiety about losing control of their children's upbringing (Jacobs, 2013, p. 116). Since Funnies ${ }^{1}$ were published in Sunday newspapers, when children were supposed to be in church and study the Bible, parents treated them as an adversary activity to their children's moral compliance (Spiegelman, 2004).

Another central argument in the polemic against comics had always been their relationship to images. The long established linguistic superiority in every aspect of official criticism and literary theory has resulted in the depreciation of images and therefore of every medium that uses them as a channel of meaning. This semiotic hierarchy however, is undeniably an ideological choice which is not scientifically legitimized, but socio-culturally (Gee, 1996, pp. 54-57).

The term Graphic novel was first coined in 1978 when Will Eisner, in search of a publisher for his legendary A contract with God and in an attempt to eliminate comics' biased perception as mass and non-quality products, spontaneously invented the term (Jacobson, 2007, p. 45). Although the work does not formally correspond to

Moula Evangelia, Ph.D., Secondary Education, Greece.

Christodoulidou Louiza, Ph.D., Assistant Professor, University of the Aegean, Greece.

${ }^{1}$ Funnies are supposed to be the precursor of comics, the fist newspaper insert in the 20's, published by Dell publishing. 
what we now recognize as a graphic novel, its innovation was justified by the autobiographical dimension of one of the four brief stories it contained, which gave the medium a new impetus. Since then, graphic novels have eliminated the stigma of low cultural products and they have delineated their own course, by evolving their techniques, conventions and themes, demanding a different, almost literary approach.

However, attempts to strictly categorize comics and graphic novels into clearly defined groups of common features prove that the differences between them are imperceptible (Dittmar, 2008, p. 25) or that there is not yet a universal convergence among academics about them. Recently a list of seven criteria were formulated (Hescher, 2016, p. 58) which could be applied to graphic stories and the sum of which seems to offer a relatively safe ranking index.

No matter what, the term graphic novel has even strengthened the existing distinction between high and low, significant and secondary and has almost established the already existing ghettoisation of comics, either because of their inherent nature (as in the case of humor works) or because of their readership (less literate groups, children, etc.) (Labio, 2011, p. 126).

So, graphic novels, in an attempt to restore the long-term disparagment against comics, they turn to the device of self-referentiality in order to deconstruct the predominant biased views concerning their "ancestors" status (Christodoulidou \& Moula, 2018). At the same time, they express themselves meta-textually, exercise criticism on the institutional background of art and this way, they contribute to the better understanding and the consolidating of the medium's academic identity.

\section{Graphic Narratives’ Self-referentiality}

Self-referentiality, despite its long presence in the field of art, is considered to be one of the most distinguished and widely discussed conditions of postmodernity (Noth, 2001) and meta-pop culture (Dunne, 1992), as the media, after the bankruptcy of the great narratives (Lyotard 1979: 27) are becoming more and more self-reflective and self-referential.

The metafictional-self-referential techniques (Waugh, 1984, p. 2) outline and disclose the processes of narrative creation by foregrounding its conventions and at the same time emphasize the illusion of truthfulness and the constuctedness of a story (Economidou, 2011, pp. 78-87). The basic devise that serves the above process is the metalepsis, namely the violation of narrative levels (Genette, 1980, p. 236). This mechanism allows the questioning and the indirect criticism not only of the subject matter of the narrative, but also of the cultural context that receives it.

Although in most art forms self-referencing is considered a sign of sophistication and maturation, a prerequisite for the artist's realization of the inherent limitations of his art or his/her lack of autonomy over its conventions, in comic books it has always been a common practice. Originally it was part of the comics' strategy to win publicity and cause laughter.

Self-references in comics were divided into three main categories: crossover (heroes from other comic books crossing boundaries and appear in other stories), parody / imitation of style or content, and foregrounding of their material or technical dimension at the narrative level (Inge, 1995, p. 11).

The evolution of the medium and the emergence of graphic novels elaborated the function of self-refernece as well. The abound versions of self-referentiality in graphic novels lately, are part of the "internal legitimization 
apparatus" of the medium, in order to progress from infra-cultural object, designated as morally harmful and artistically impoverished, to para-cultural object (Lecigne, 1985, p. 7), or even to a worthy cultural asset. A variation of the self-referential techniques is the "metaphorisation of the code" (Groensteen, 1990, p. 163), which comprises the medium's graphic material, its specific mode of representation, its production processes and the (social) institutions surrounding it (p. 133). Manifestations of the metaphorisation of the code allow us for a more critical reflection upon the medium.

\section{Graphic Novels Deconstructing Clichés and Redefining Comics}

Graphic novels by self-referencing on the mode of their cultural representation, they exercise criticism on the cultural establishment, reframe and redefine comics (Christodoulidou \& Moula, 2018). Such an acute criticism about the underestimated position of comics in the art world and their categorization as non- art can be found in Pussey! by Daniel Clowes. At Pussey's meeting with the trainer who undertakes to educate and enlighten the aspiring comic artists in Dr. Infinity's Industry (p. 20), when she calls Pussey a cartoonist, he corrects her, suggesting the term comic artist. The implicit underestimation underlying the term cartoonist is rejected and replaced by a word, more highly appreciated.

In Eddie Campbell's Alec, How to be an artist (2000), he gives his own definition about comics (p. 17): "Comics if not this hobbyist thing, like collecting bottle-cups, is mostly this very conservative nostalgia-for-childhood thing. Some guys learn to draw just so they can fulfill the ambition of being hires to continue the adventures of their childhood hero". On the other hand the career officer declares "the people who draw comics are people who aimed higher and failed". These two statements represent the most common beliefs about comic artists, but they aim at undermining them.

In The Horrible truth about comics, Kochalka wandering in his dream world, attempts a theoretical reconstruction of the medium, trying to demonstrate his uniqueness and intrinsic value. Through an inductive reasoning he manages to associate comic books with art, with play and with the deeper human need for self-expression and creativity. He disassociates design skillfulness from art and underlines the importance of inspiration. Equally, he claims that comics develop in a similar way to that of brain neurons, spreading and branching, hence they offer us a privileged path to our inner self. Regardless of the degree of scientific precision of his arguments, the artist tries to rationalize his personal passion for comics and convince his audience for their self-justifying value.

In Jason's Pocket full of rain, his anthropomorphous hero discusses on equal terms with him during a "vertical metalepsis" (Meyer-Minnemann and Schlickers, 2008)—which "moves from high to low (Pier, 2005, pp. 136, 140, 147), thus making it a descending one (Pier, 2005, pp. 253-254).

The dog-faced hero, while embodying the original iconographic tradition of comics, accuses the heroes of the film he had just watched, of being as flat as comic book characters, a statement that contradicts with his own self to the point of self-refutation. Through this trick, the cliché view about comics as low cultural products, uttered by a genuine representative of the medium, invites the reader to reflect upon the subject and to negotiate the common belief, judging only from the narrative universe itself. The dog-like interlocutor speaks in such a sophisticated manner, akin to film criticism, upgrading this way the potential of comics' language and discourse. 
In Jimmy Corrigan: The Smartest Kid on Earth by Chris Ware, one can spot-embedded in the demanding and multilevel narrative-, inserts that mimic the origins of comic magazines in a self-mocking mood. Dr. James Corrigan in the supposed insert, undercuts and undermines Chris Ware's psychoanalytic dimension of his partially autobiographical narrative. At the same time he laughs at the rhetoric that justifies comic books through an exhaustive discourse analysis and the search of their deeper meaning. Dr. James Corrigan — casted in the mold of the crazy scientist - attempts, through a totally unrealistic and paradoxical way of reasoning, to point out the hidden messages under the surface of comic books, proving exactly the opposite. This short embedded insert causes a rupture at the main - serious- narrative and lets the steam of it go, but eventually being framed by and embedded in it, it validates it and confirms that the medium of comics does not need any "good-natured" recommendations or external support, since it can achieve its self realization.

Brooklyn Dreams by J. M. DeMatteis, is a retrospective narrative in which an adult's narrative self tries to reconstruct his young narrating self, through an unceasing fusion of temporal narrative levels. At a certain point of the story, the narrator discovering an old diary of his, whose melodramatic tone resonates his then agonizing search for identity, he monologues: "What could one expect .... After I grew up with comic books? Once again, in a sophisticated on a content, technical and narrative level graphic narrative, the author reiterates the denigrating stereotype for comic books, while his very work undermines it” (De Matteis, 1994, p. 273). Commenting on the reception of the medium, the graphic narratives of modern creators weave a completely different "literary" tradition, restoring the medium's reputation by itself.

In Dylan Horrocks's Hicksville, Batts, the researcher, through his own nostalgic adherence to comic books, articulates his own subjective definition: "comics were a way out. My private world where people were strong and beautiful and lived meaningful and exciting lives. They lived in clean places, bright and sunny and comfortable.... and they wore stupid spandex costumes and spoke in pre-school vocabularies" (Horrocks, 2014, p. 115). The synthesis of these contradictory elements corresponds to the rule of mainstream commercial comics of the golden age and despite the latent irony in the attempted definition, the right to self-realization of the medium is claimed, at least, as a way to escape from the pressing reality.

Alice in Sunderland by Bryan Talbot is an impressive metafictional graphic novel exploring the relationship between Lewis Carroll and the Sunderland region, along with wider issues of history, myth, storytelling, and comic book history and theory. The structure of the graphic novel is influenced by the nonsense tradition and the complex, mathematical reasoning of Carroll, as the narrative levels are inextricably interwoven. The narrative evolves as a theatrical performance, much of which is devoted to the "ninth art".

The narrator predicts the low public response to his venture and its financial fiasco, by presenting himself performing in Empire Sunderland's empty theater with a lone and bored viewer as his audience. This inaugural selection of space and conditions (settings of storytelling) is a form of indirect protest for the ignorance and devaluation of comic books. The narrator, among other things, wanders back, at the artistic predecesors of the comics, and presents us the masterful tapestry of Bayeux or the Gin Lane and Beer Street paintings of Hogarth, treated as comics without panels. The narrator brings up many opportunities to clarify the role of comics and to defend them. In an intuitive phase of consciousness awakening and self-criticism, he realizes that the work he composes can not be considered as a comic book, because it does not obey to the conventions of the medium, meaning it does not deal with caped heroes with tight trousers and inflatable muscles, so he is doomed to failure. 
In this outbreak of despair, one can trace the stereotypical perceptions that shrink the field of action and function of the comics into that of the superheroes genre. Also, an imperceptible bitterness is detected in the narrator's assumption that in France comics are totally accepted as a respectable art, unlike other countries. Later, in an embedded narrative the narrator transformed into a hero of BD's clear line style, (a Tin Tin's hero), meets a wandering storyteller, somewhere in Africa and he compares his art to comics, with the difference that the storyteller uses words and performance. Through this comparison, he proposes an alternative conceptualization of comics as narrative medium and claims their cultural recognition.

\section{Metatextual Commentary on Art, Comics, Theory ... and in Between}

Metatextuality, is the more commonly referred to as "comment" and unites a text with another text, without necessarily quoting or naming it. It is an allusive and silent reference, par excellence a critical relationship between texts (Genette, 1997, p. 13). In our case, it can be extended to comprise all critical commentary articulations on the artistic phenomenon in general and on comics' history and theory in particular.

First of all, graphic novels sometimes reflect upon and comment on the academic theory of comics.

In Hicksville, during Grace and Sam's visit to Emil Kopen, the most celebrated Cornucopia comic artist, Sam asks him why he calls himself a cartographer. He initially explains that in his language the word for comics, piktorii, means word-pictures, despite the fact-he adds - that words are not always necessary in the narrative. This explanation is a direct hint to the long controversy between comic theorists about the importance of the two main components of comics, words and images. Words, though in a cooperative-complementary relation to pictures, within a varying range of signifying degree, are considered by many contemporary scholars to be a secondary component of the medium, despite the existence of works based exclusively on speech balloons (Meskin, 2009).

Afterwards, Emil Kopen develops his theory of the existence of two kinds of maps, those who present the place of things in space and those referring to the position of things in time, or rather their evolution in it, serving a geography of time. He believes that stories talk about space-to-space relationships, while time is nothing but what intercedes between them. The mini lecture of the imaginary artist refers directly to Scott McCloud's (2000, p. 206) theory of comic books as temporal maps, which Neil Cohn (2010) evolved and modified by identifying its vulnerabilities. The passage has a metatextual quality, as it raises issues of theory and interpretation of the medium and allows the reader to look at the academic rhetoric that supports it.

In Talbot's Alice in Sunderland, during a night-time awakening of the narrator, overwhelmed by existential questions and anxiety about his artistic choices, the sudden appearance of Scott McCloud, one of the founders of comic theory, as deus ex machina, appeases him, by reminding him of the difference between the medium and the literary genre. Comics as a medium - he emphatically claims- can serve all kinds of genres. This echoes the equally much controversial confrontation of academics in their effort to define comic books. The liquidity in comics terminology (Pratt, 2009) also reflected the volatility of the comic books' academic stature (Hartfield, 2009, p. 23), which in turn justified their poor social reception.

In The horrible truth about comics, Kochalka contends that comics create an entire universe in their own secret code, which has the ability to be inscribed in the mind of the reader in a simple and comprehensible way. This view is clearly related to the theory of double coding as formulated by Clark and Paivio (1991). According to 
it, comics by combining and coordinating the two basic codes they employ, the language and the images, achieve a more effective inscription of their messages in memory.

Furhtermore, graphic novels contemplate on the concept of art, its institutions and its promotion mechanisms.

In Pussey!, the trainer of the new entrants and wannabe artists in the comics industry, during their informative seminar, reveals unwittingly the scandalous affinity and the equally impermeable limit that separates comics from the world of high art.

Thus, against the poorly paid and degraded work of those working in the comic book industry one is forced to juxtapose the 16-volume exuberant autobiography of a successful painter, whose primitive cartoon-like designs on a large scale would leniently be considered as trash, if they were addressed to the comic book industry. Equally, the provocative policy of Highbrow comics is denounced, since the company profiteered, by creating supposed to be- works of art from random pages of its issues. The culmination of this fake, occasional artistry is the painter who enjoys recognition and fabulous profits thanks to the copying of panels from Pussey's comic book and their transfer to a large scale. This sounds as a latent insinuation about the huge success of the 60ies famous pop artist Roy Lichtenstein.

A similar comment is made by Eddie Campbell's Alec, How to be an artist, a graphic novel inspired by the artist's own experiences in the field of comics. He wonders about the nature of art and questions straightforwardly Roy Lichtenstein's artistic qualifications and his success based on comic strips (Campbell, 2000, p. 15).

All the above question the dividing boundary between comics and art while at the same time lay high art bare from its embellishment and idealizations. The technique of parodic stylization (Bakhtin, 1980, p. 312) creates a double-edged hybrid narrative construction (Bakhtin, 1980, p. 306) that allows for a distancing from what is told, through the prism of what is shown. As the officially recognized authoritative belief system of the narrator contradicts and contrasts the particular point of view of the pictorial narrator, the reader has the chance to see the object of representation in a new light, as a different-true-dimension is portrayed and revealed. The excerpt is a commentary on comic books and art and even more on the arbitrariness of the dominant criteria, recalling Bourdieu's (1984) theory about cultural capital and the mechanisms of its establishment and propagation.

In Alec. How to be an artist again, the hero reflects on graphic novel (2000, p. 120), saying that it is a misnomer as it has been comic book. Pedants will want to subdivide it as though a novel has a prescribed weight, into novella and novelette with a disregard for the origins of the words.... Some will be bad, some dull, perhaps the worst crime a comic can commit. Some will be no more than regular comics dressed up pretentiously". These words echo the long discussion about the indeterminate blurred boundaries between comics and graphic novels and even denounce the scholars' zeal on categorizations (Chinn-McLoughlin, 2007, pp. 14-15).

Another denouncement of the sophisticated analyses that aim at the ideological upgrading of the medium of comics is to be found in Alec who mocks Moliterni's profound analysis of Hogarth's narrative technique on Tarzan (Campbell, 2000, p. 54). This metatextual comment is a kind of an indictment of the scholars' coordinated effort to legitimize the medium through the official mechanisms of the literary establishment. 
In Alec's philosophical ruminations one may also find an interesting metaphor about art (Campbell, 2000, p. 57) as well: "The map of the history of art is like any other map. There are main roads and side streets, old masters and lesser masters.... However the pleasantly naive among us may think that the measure of art is that is has passed the test of time. No map remains for long an accurate representation of the locale. Favour ebbs and flows. This well formed statement recalls the model of cultural evolution, as articulated by Lotman and constructed after the Nobelist Ilya Prigogine's description of biological and physical processes. Cultural evolution is predictable only to a certain point, a critical moment when something crucial happens and is called bifurcation point. After this, there is an indefinite number of possible paths. At the same time there is also a slow movement of new innovative phenomena from the periphery of the semiosphere towards the centre" (Nikolajeva, 1996), which replace the once mainstream phenomena, loosing at the same time their flexibility, adaptability and their refreshing quality.

Another serious metatextual excerpt is the one discussing the relation between Art and Craft. "The idea that art and craft are driving opposite sides of the street is relatively new. It derives from another journalistic diversion, the myth of the romantic artist-outsider. Like Van Gogh lopping his era off, Shelley at Lerici aflame on the beach, age $23 . .$. In the past not only were art and craft not seen as separate operations but craft was universally held in much higher esteem" (Campbell, 2000, p. 58).

This is an attempt to redefine art, by laying the whole theory and history of the art bare of critical distortions and interpretations, that served time and power specific interests and authorities. It is also reminiscent of the role of experts in explaining art and of the long standing controversy, first raised by Plato, about the relation of form and content. On the one hand, formalism (newformalism as well) claims that "where the mode of articulation is fitting or particularly relevant or apposite to the work's content, we derive a satisfying sense of unity from the artist's craftsmanship in matching form with content" Even more, "The critics help us by showing us where to look and how to understand what we find" (Carroll, 1999, p. 130). On the other hand, neo-representational theory of art defends and stands for the perceptually indiscernible, separating art from labor or craft and claiming vagueness and ambiguity as a necessary property of art. (Carroll, 1999, p. 28). At the same time this comment taunts the eccentricity and the myth of the charismatic artists, in accordance with Raymond Williams' theory that all the artistic forms are the result of "processes, physical and material", historical variables of real social relationships, both general and specific. (Williams, 1977, pp. 190-191)

\section{Conclusion}

Graphic novels turn into self-referential contemplative metatexts in order to enable the readers to view the artistic world and the existing clichés about comics from more than one perspective and to realize the existence of multiple versions of the truth (Green, 2001). Taking advantage of self-referentiality's potential, they use it as an 'internal legitimization apparatus' of the medium, to upgrade it from infra-cultural object (Lecigne, 1985, p. 7), designated as morally harmful and artistically impoverished, to a worthy cultural asset.

Graphic novels by self-referencing on the mode of their stereotyped representation and reception, they exercise acute criticism on the cultural establishment, while reframing and redefining comics in an attempt to culturally upgrade them. 
They also use metatextuality as a pretext for their partaking at theoretical discourse about art in general and comic art in particular, proving that contemporary comic artists, being aware of the field's critical and theoretical evolution, claim their right to participate in the academic discourse and even judge, negotiate, or rearticulate it.

\section{References}

Bakhtin, M. M. (1980). Questions of literature and aesthetics (greek translation George Spanos). Athens: Plethron.

Bourdieu, P. (1984). Distinction. A social critique to the judgment of taste (R. Nice, Trans.). Cambridge-Massachusetts: Harvard University Press.

Chinn, M., \& Mcloughlin, C. (2007). Create your own graphic novel. Cambridge: Ilex.

Christodoulidou, L., \& Moula, E. (2018). Graphic narrative: Ciritcal literacy and self-referential reframing of the field. Keimena, issue 26. January 2018 (in Greek-to be publshed).

Chute, H., \& Dekoven, M. (2006). Introduction: Graphic Narrative. $\Sigma$ to H. Chute and M. DeKoven (Eds.). Graphic Narrative. Special issue of Modern Fiction Studies, 52(4), 767-782.

Clark, J. M., \& Paivio, A. (1991). Dual coding theory and education. Psychology Review, 3(3), 149-170.

Cohn, N. (2010). The limits of time and transitions: Challenges to theories of sequential image comprehension. Studies in Comics, 1(1), 127-147.

Comber, B. (2001). Classroom explorations in critical literacy. $\Sigma \tau$ o H. Fehring, and P. Green (Eds.). Critical literacy: A collection of articles from the Australian Literacy Educators' Association (pp. 90-111). Newark, Delaware, International Reading Association.

Dittmar, F. J. (2008). Comic-alalyse. Konstanz UVK-Verl-Gesselschaft.

Dunne, M. (1992). Metapop: Self-referentiality in contemporary American popular culture. Jackson: University Press of Mississippi.

Gee, J. (1996). Social linguistics and literacies ideology in discourses (2nd ed.). London: The Falmer Press.

Genette, G. (1997). Palimpsests: Literature in the second degree. Nebraska: University of Nebraska Press.

Genette, G. (1980). Narrative discourse: An essay in method. (J. Lewin, Trans.). Ithaca: Cornell University Press.

Green, P. (2001). Critical literacy revisited. $\Sigma \tau$ o H. Fehring and P. Green (Eds.). Critical literacy: A collection of articles from the Australian Literacy Educators' Association (pp. 7-13). Newark, Delaware: International Reading Association.

Groensteen, T. (1990). Bandes désignées: de la réflexivité dans les bandes dessinées. Conséquences 13/14: Contrebandes: $132-165$.

Hall, S. ([1973] 1980). Encoding/decoding. In Centre for Contemporary Cultural Studies (ed.), Culture, media, language: Working papers in cultural studies, $1972-79$ (pp. 136-138). London: Hutchinson.

Hartifeild, C. (2009). Defining comics in the classroom; or, the Pros and cons of unfixability, teaching the graphic novel. In E. S. Tabachnick (Ed.), Teaching the graphic novel (pp. 19-27). New York: The Modern Language Association of America (MLA).

Hescher, A. (2016). Reading Graphic Novels. Genre and Narration. De Gruyter.

Inge, M. T. (1995). Anything can happen in a comicstrip. Centennial reflections on an American art form. Ohio State University Libraries, University Press of Mississippi and Randoph- Macon College.

Jacobs, D. (2013). Graphic encounters. Comics and the sponsorship of multimodal literacy. New York, London, New Delhi, Sydney: Bloomsbury.

Jacobson, S. (2007, May-August). After the graphic novel. The New Leader, 90(3/4), 45.

Labio, C. (2011). What's in a name? The academic study of comics and the "graphic novel". Cinema Journal,50(3), 123-126.

Lecigne, B. (1985). Editorial in Controverses 1 (pp. 5-23). Paris.

Lewis, D. (2012). Reading contemporary picturebooks: Picturing text. London and New York: Routledge/ Taylor and Francis.

Lyotard, F. (1979/1984). The postmodern condition. Manchester: Manchester University Press.

Mccloud, S. (2000). Reinventing comics: How imagination and technology are revolutionizing an art form. New York: Perennial.

Meskin, A. (2009). Comics as literature? British Journal of Aesthetics, 49(3), 219-239.

Minnnemanm, M., \& Schlickers, S. (Eds.). (2008). La novela picaresca. Concepto genérico y evolución del género (siglos XVI y XVII). Madrid-Pamplona, Vervuert

Moliterni, C. (1972). Narrative technique. Graphis 28 (159): 26-43 in W. Herdig and D. Pascal. The art of the comic strip. Zurich: The Graphis Press.

Nikolajeva, M. (1996). Children's literature comes of age: Toward a new aesthetic. New York: Routledge. 
Noth, W. (2001). Autorreferencialidad en la crisis de la modernidad. Cuadernos: Revista de la Facultad de Humanidades y Ciencias Sociales, 17, 365-369.

Pier, J. (2005). Métalepses et hiérarchies narratives. $\Sigma \tau$ o J. Pier and J. -M. Schaeffer (Eds). Métalepses. Entorses au pacte de la representation (pp. 133-150). Paris: Éd. de l'EHESS.

Pratt, H. J. (2009). Narrative in comics. Journal of Aesthetics and Art Criticism, 67, 107-117.

Sabin, R. (1996). Comics, comix \& graphic novels: A history of graphic novels. London: Phaidon Press.

Tabbi, J., \& Wutz, M. (Eds.). (1997). Introduction to reading matters: Narrative in the new media ecology (pp. 1-25). Ithaca N.Y.: Cornell University Press.

Waugh, P. (1988). Metafiction: The theory and practice of self-conscious fiction. London: Routledge.

Williams, R. (1977). Marxism and literature. Oxford: Oxford University Press.

Moula, E., \& Konstantinos, M. (2015). Word clouds: Comics and new literacies. Athens: Comicon.

Oikonomidou, S. (2011). A Thousand and one subversions. Modernity in literature for young ages. Athens: Patakis.

\section{Works cited}

Campbell, E. (2000). Alec, how to be an artist. Eddie Campbell Comix.

Clowes, D. (2012). Pussey! Fantagraphics Books, Inc.

Dematteis, J. M., \& Glenn barr. (1994). Brooklyn dreams. Paradox Press.

Horrocks, D. (2014). Hicksville: A comic book. Drawn \& Quarterly.

Jason, FIRST NAME., \& Thompson, K. (2008). Pocket full of rain: And other stories. Fantagraphics Books.

Kochalka, J. (1999). The horiible truth about comics. Alternative comics.

Spiegelman, A. (2004). In the shadow of no towers. NY: Viking Adult. 